\title{
対話を通じた未知語のクラス獲得に向けた 暗黙的確認の提案
}

\section{Proposal of Implicit Confirmation toward Lexical Acquisition during Dialogues}

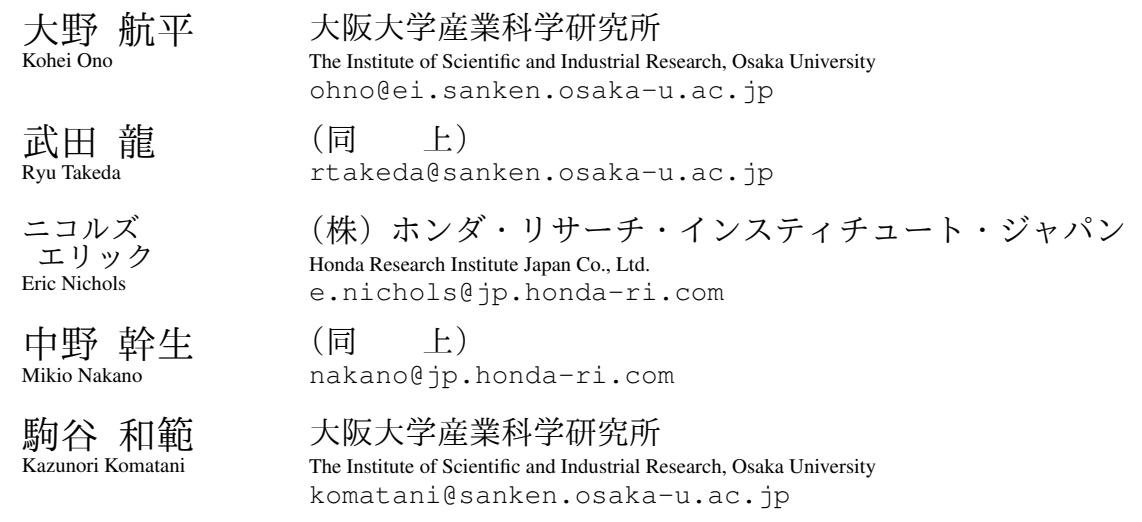

keywords: chatbot, lexical acquisition, implicit confirmation

\section{Summary}

This paper proposes a lexical acquisition framework for a closed-domain chatbot. It learns the ontological categories of unknown terms in dialogues through implicit confirmation instead of using explicit questions that disrupt the flow of conversation. Our system generates an implicit confirmation request containing an unknown term's category prediction, which may be incorrect. It then acquires the category only if its prediction was correct by checking various cues that appeared during the confirmation process. We divide this process into two steps. First, we propose a two-tiered method to predict unknown term categories that attempts to predict the most specific category and backs off to a more general category when it is insufficiently confident about its prediction. Direct evaluation showed that this two-tiered method makes correct category predictions $54.4 \%$ more often than that predicting the most specific category only. Next, we propose a method for identifying whether categories included confirmation requests are correct by using both the user response following the confirmation request and its context. We introduce features, which are derived from analysis of the confirmation process, and construct a classifier from chat data, which we collect with crowdsourcing. We show that the classifier can identify correct categories with a precision of 0.708 .

\section{1. は じめに}

近年, 非タスク指向型対話システムへの関心が高まって いる [Higashinaka 14, Yu 16]. 非タスク指向型対話シス テムは，対話によってユーザとの良好な関係を構築するこ とに効果的であるため，その機能を搭載したタスク指向型 対話システムの開発も進められている [Dingli 13, Kobori 16, Lee 09, Papaioannou 17]. 現状では, 適切な応答を 高い確率で行うオープンドメインの非タスク指向型対話 システムを構築することは困難である [Higashinaka 15]. そのため, 我々は特定のドメインについて対話を継続で きるものを開発している.

ここで課題となるのが，システムの知識にない単語（未 知語）への対応である. ユーザ発話に未知語が含まれる 場合，システムはそれに対する具体的な応答ができない.
対策として，システムの開発者による定期的なシステム の知識の更新が行われているが，追加すべき単語には際 限がないため，コストが非常に高い. Wikipedia*1などの 集合知による知識源を活用することで，新しい単語やそ れに関して対話システムが必要とする情報（単語が料理 名であれば，料理ジャンルなど）を自動的に獲得する方 法が考えられる.しかし，Wikipedia などにそれらが常に 書かれているとは限らないという問題や，単語は常に生 まれ続けるため，Wikipedia などに全ての単語の情報が 記述されるわけではない，という問題がある。 また，本 研究では, 料理に関する単語を対象として実験を行って いるが，より専門性の高い単語や地域に依存する単語な どを対象とした場合に，Wikipedia などから知識を自動 的に獲得するのは困難だと考えられる。

*1 https://www.wikipedia.org/ 


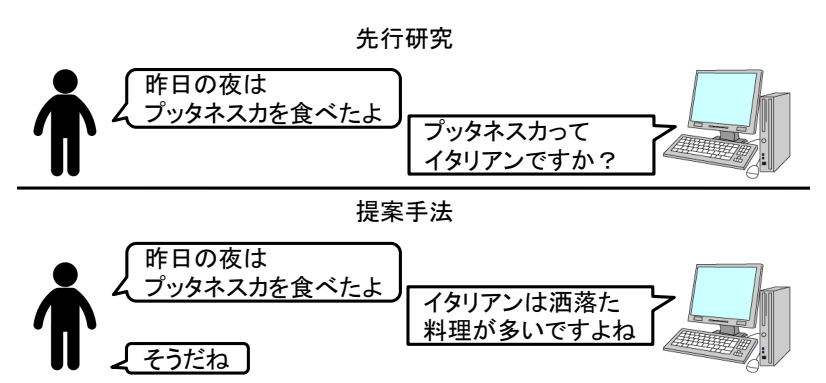

図 1 暗黙的確認を利用した未知語の獲得

システムが対話を通じて未知語を獲得できれば，開発 者が手作業でシステムの知識を更新する手間を省くこと ができる．本稿での未知語の獲得とは，未知語を知識に 存在するクラスへ位置付けることだとする．システムが 未知語のクラスを推定できれば，ユーザに質問を行い，そ れに対する応答に基づいて未知語のクラスを獲得できる [Otsuka 13]. 例えば図 1 上に示すように，未知語「プッ タネスカ」のクラスが「イタリアン」であると推定でき れば,「プッタネスカってイタリアンですか?」といった 質問ができる．しかし，対話においてこのような単純な 質問を繰り返し行うと，ユーザは煩わしさを感じる。特 にクラスの推定結果が誤りであった際に，それは顕著で あると考える。

本稿では, 暗黙的確認を用いてょり自然に対話を継続 しつつ未知語のクラスを獲得する手法を提案する. シス テムは未知語のクラスを推定し，その結果が正しいとみ なして発話を行い，それに対するユーザの応答に基づい て未知語のクラス獲得を狙う. 図 1 下に示すように, シ ステムは未知語「プッタネスカ」のクラス「イタリアン」 について,「イタリアンは酒落た料理が多いですよね」と いった暗黙的確認要求を出力する. 暗然的確認要求によ り，明示的な質問を用いるよりも自然に対話を継続でき ると仮定した。この仮定の正しさについては, 暗黙的確認 要求と明示的な質問に対するユーザの印象の比較を行う ことで検証する必要があるが，それは今後の課題とする.

この手法による未知語のクラス獲得を実現するために, 2 つの課題に取り組んだ. まず, 適切な確認要求を出力し て対話を継続するために，2段階で未知語のクラスを推定 する. システムが未知語の誤ったクラスに基づく確認要 求を出力すると, ユーザは困惑すると考える. 未知語の 具体的なクラスを推定できない場合には，より抽象度の 高いクラスを推定することで, 対話を継続させるための 適切な確認要求を出力することを狙う. 次に, 確認要求 に含めたクラス推定結果の正誤をユーザの応答から判別 する. 明示的な質問の場合とは異なり, システムの暗黙的 確認要求に対して，ユーザがその内容の正誤を明示的な 同意や反対の表現で示すとは限らない，そのため，同意 や反対を明示的に示す表現だけでなく，それ以外の表現 も考慮して, 確認要求に含めたクラスの正誤を判別しな

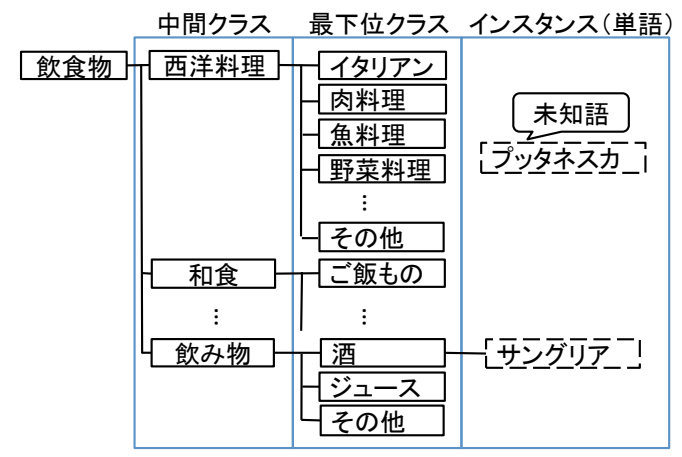

図 2 食ベ物・飲み物のジャンルを表すオントロジー

ければならない. 本稿では, ユーザ応答を用いてクラス の正誤判別が可能かどうかを検証する. 正しいクラスま たは誤ったクラスを含む暗黙的確認要求を人手で準備し, それに対するユーザ応答を収集して評価実験を行った。

本稿の構成を以下に述べる. まず 2 章では, 暗黙的確 認を利用した未知語のクラス獲得の全体像と, その実現 のために取り組んだ 2 つ課題の概要を述べる. 3 章で は, 先行研究を紹介したうえで, 本研究の位置づけを述 ベる. 4 章では, 2 段階でのクラス推定手法の詳細を述 ベ, この手法により正しいクラスに基づく確認要求を出 力できる割合が増加することを示す. 5 章では, 確認要 求に含めたクラスの正誤判別手法について, 設計した素 性と正しいクラスに基づく確認要求の抽出性能について 述べる. 6 章では本稿の総括を行い, 今後の課題につい て述べる.

\section{2. 暗黙的確認を利用した未知語獲得}

暗黙的確認を利用した未知語の獲得処理は, 以下の 3 ステップからなる.

(1) システムが知識として持つオントロジー上のクラ スのうち，未知語がどれに所属するかを推定する

（2）推定結果に基づいて暗黙的確認要求を生成する

（3）確認要求前後のユーザ発話を用いて, 確認要求に 用いたクラスの正誤判別を行う

ここで, システムは知識構造として単純な階層構造を 有するオントロジーを持つとする.これは図 2 に示す通 り深さが 3 段であり, 最上位クラス, 中間クラス, 最下 位クラスからなる. システムの知識に存在する単語は全 て，オントロジー内の最下位クラスに所属するインスタ ンスであるとする. 未知語の獲得とは, 未知語をオント ロジー上の最下位クラスのいずれかに位置付けることと 定義する.

暗黙的確認による未知語の獲得処理を, 図 1 下半分の 例を用いて説明する。はじめにユーザは, 未知語「プッ タネスカ」を含む発話「昨日の夜はプッタネスカを食べ たよ」を入力している。ここで,「プッタネスカ」につい 
ての最上位クラスが「飲食物」であることは, 固有表現 抽出などにより得られるとする．まず，システムは「プッ タネスカ」の属する最下位クラスが「イタリアン」であ ると推定できたとする (ステップ(1)) 。次に, 推定結果 を用いて「イタリアンは酒落た料理が多いですよね」と いった暗黙的確認要求を出力する (ステップ(2)). それ に対するユーザの同意を示す応答「そうだね」から，未 知語「プッタネスカ」の所属する最下位クラスが「イタ リアン」であることが同定できる（ステップ(3)）。

暗黙的確認による未知語の獲得には，2つの課題があ る. 1つ目は, ステップ(2)において, 誤ったクラス推定 結果に基づいて確認要求を出力してしまうと, ユーザが 困惑してしまう点である. 2つ目は, ステップ(3)を行う ためには, 確認要求に対するユーザ応答に現れる同意・ 反対表現に着目するだけでは不十分だという点である.

1 つ目の課題について述べる. 例えば，システムがス テップ (1) で未知語「プッタネスカ」の最下位クラスを 誤って「洋菓子」と推定し, ステップ (2) で「洋菓子は 味が濃厚なものが多いですよね」のような確認要求を出 力した場合を考える，このときユーザは，話題が「プッ タネスカ」から「洋菓子」へと唐突に変わったため, 確 認要求に対してどのように応答すればよいか困惑すると 考えられる。これを防ぐために，最下位クラスの推定結 果が十分に信頼できない場合には, 最下位クラスに基づ いた具体的な確認要求の出力を諦め, より抽象度の高い 適切な確認要求を出力する。これにより, 自然な対話を 続けることができると考える.

$2 つ$ 目の課題について述べる. Yes/No 質問によって未 知語を獲得する場合, ステップ (3) に相当する部分では, ユーザ発話中の「はい」や「そうです」といった同意を示 す表現や,「いいえ」や「違います」といった反対を示す表 現を検出することで，未知語の正しいクラスを獲得でき る.一方で暗黙的確認を用いた場合，ステップ (3)ではこ れに加えて様々な表現が現れる. 図 3 上の例では, 「カオ マンガイ」に関するユーザ発話に対し，システムは正し いクラス「エスニックフード」を用いた確認要求を出力 している. 一方, 図 3 下の例では,「ユーリンチー」に関 するユーザ発話に対し，システムは誤ったクラス「和食」 を用いた確認要求を出力している，両者において，確認 要求に含めたクラス推定結果の正誤を判別するためには, 正しいクラスあるいは誤ったクラスに基づく確認要求に 対するユーザ応答の，傾向の違いを捉える必要がある.

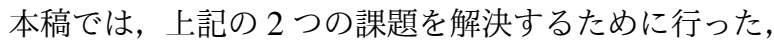
以下の 2 つの取り組みについて述べる。

(a) ステップ (1)における 2 段階での未知語の所属ク ラス推定

(b) ステップ (3) における確認要求前後のユーザ発話 を考慮した正しいクラスに基づく確認要求の抽出

まず，適切な確認要求によりユーザとの自然な対話を 継続するために，所属クラスの推定を 2 段階で行う。最
確認要求に用いたクラスが正しい

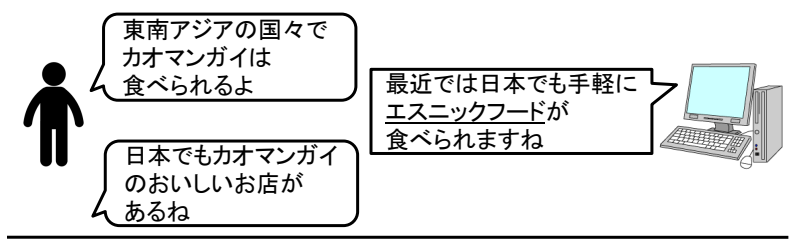

確認要求に用いたクラスが誤り

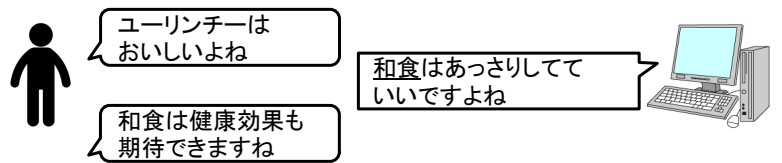

図 3 確認要求後のユーザ発話中の同意・反対表現に注目するだけ では，正しいクラスに基づく確認要求を抽出できない

下位クラスの推定結果が十分に信頼できない場合，一つ 上位にあたる中間クラスレベルでの推定を行う．例えば システムが未知語「プッタネスカ」について，中間クラ ス「西洋料理」を推定できた場合,「西洋料理は子供に人 気のメニューが多いですよね」といった確認要求を出力 する．この場合，未知語の所属する最下位クラスの同定 はできず，また確認要求の抽象度が高くなるといった問 題があるが，誤ったクラスに基づく確認要求や明示的な 質問よりも自然な応答ができると仮定した。中間クラス レベルの推定結果も信頼できない場合には,「プッタネス カってどんな料理ですか?」といった単純な質問を出力 する.

次に，ユーザ応答に基づいて，暗黙的確認要求に含めた クラスの正誤判別が可能かどうかを検証する．未知語と する単語の入力をユーザに依頼し，その単語の正しいク ラスまたは誤ったクラスを含んだ暗黙的確認要求をユー ザに示すことで，それに対する応答を収集し分析を行う。 ここでは，正しいクラスあるいは誤ったクラスに基づく 確認要求に対するユーザ応答の傾向の違いを分析し，正 しいクラスに基づく確認要求の抽出に有効と考えられる ユーザ発話中の表現を素性として設計する.このとき, 確 認要求後のユーザ発話だけでなく, 確認要求前のユーザ 発話や，両者の関係も考慮する。

\section{3. 関 連 研 究}

対話を通じて未知語のクラスを獲得するための研究は これまでにも行われている．Holzapfel らは，ロボットが 反復的に質問を行うことで未知語のクラスを獲得する手 法を提案した [Holzapfel 08]. Otsuka らは，クラス推定結 果とその確信度に基づいてユーザに質問を行い，それに対 する応答に基づいて未知語のクラスを獲得する手法を提 案した [Otsuka 13].さらに Komatani らは，期待効用に 基づいて適切な質問を選択する手法を提案した [Komatani 16].これらの手法はいずれも明示的な質問を用いており, 
システムがそれを繰り返すとユーザは煩わしさを感じる と考える. 本研究では, 暗黙的確認により自然な対話を 継続しつつ未知語のクラスを獲得することを狙う．Pappu らは, 対話を通じてドメイン固有の単語間の関係を獲得 する手法を提案したが [Pappu 14]，その関係を獲得する ためには, 先に本研究の手法によって未知語のクラス獲 得を行う必要がある.

未知語のクラス推定に関する研究も行われている. Meng らや Takahashi らは, 未知語の固有表現レベルのクラス を推定する手法を提案した [Meng 04, Takahashi 02]. 本 研究では，より具体的なクラスを獲得することを目標と している. Otsuka らは，未知語の文字の分布やWeb 検 索結果に基づいて，未知語の具体的なクラスを推定する 手法を提案した [Otsuka 13]. Otsuka らの手法では最下 位クラスの推定しか行っていないが，本研究では 2 段階 でのクラス推定を行うことで, 適切な確認要求により対 話を継続できる場合を増加させることを狙う。

正しいクラスに基づく確認要求の抽出に関連する研究 として，ルールや機械学習を用いて文が肯定的なものか 否定的なものかを分類するものがある. Marneffe らは, Yes/No 質問に対する応答が，明示的にどちらかを示す ものではなかった場合に，それがどちらの意図を示して いるのかを判定するためのルールを作成した [Marneffe 09]. Gokcen らは, Web 上で行われた議論のコーパスか ら, 議題に対して反対の立場をとる投稿を抽出するため の素性設計を行った [Gokcen 15]. これに対して本研究 では，応答や文そのものを分類するためではなく，正し いクラスに基づく確認要求を抽出するために, ユーザ発 話の表現や確認要求前後のユーザ発話間の関係に基づい て素性設計を行う.

本研究での未知語のクラス獲得は, 確認要求に対する ユーザ応答がクラス獲得の指標となっている点から, 暗黙 的な教師あり学習の一例と捉えることができる [Banerjee 07, Komatani 09]. ただし, Banerjee らやKomatani らの 研究とは獲得の対象が異なる.

\section{2 段階での未知語の所属クラス推定}

\section{$4 \cdot 1$ クラス推定の手順}

未知語の所属クラスの推定処理のフローチャートを図 4 に示す. 推定には, 未知語がそのクラスに所属する確 信度を用いる. 所属クラスの推定は, (1) 各最下位クラス に確信度 $C M 1$ を付与する, (2) $C M 1$ が最大となる最下 位クラスを推定結果とし，その $C M 1$ がしきい值 $\theta_{1}$ 以 上の場合, 推定結果を受理する, (3) $C M 1$ が $\theta_{1}$ 未満の 場合は推定結果を棄却し, $C M 1$ を用いて各中間クラス に対して確信度 $C M 2$ を算出し，しきい值 $\theta_{2}$ を用いて 手順 (2) と同様に推定する，という手順で行う。手順 (2), (3)において推定結果が受理された場合，システムはそれ ぞれ最下位クラス, 中間クラスレベルの推定結果を含む

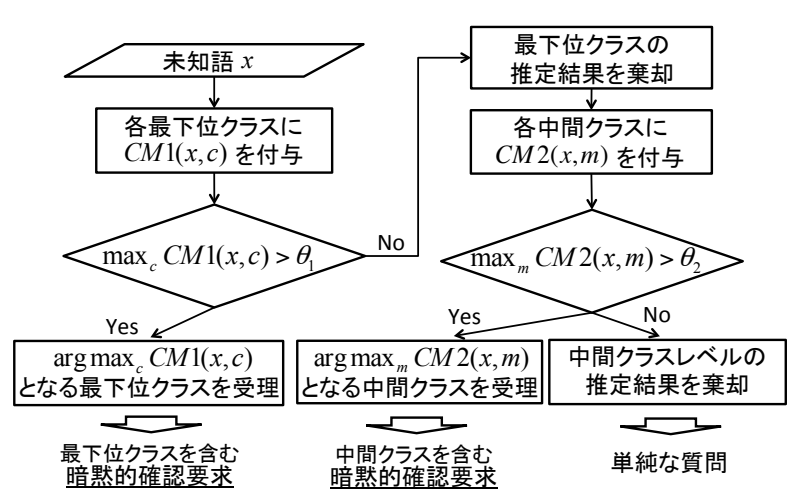

図 42 段階でのクラス推定処理

確認要求を出力する. どちらの推定結果も棄却された場 合，システムは単純な質問を生成する.

未知語 $x$ が, 中間クラス $m$ の子クラスのいずれかに 所属する確信度 $C M 2(x, m)$ を, 次のように定義する.

$C M 2(x, m)=\sum_{c \in \operatorname{child}(m)} C M 1(x, c)$

ここで, $\operatorname{child}(m)$ は中間クラス $m$ の子クラスの集合, $C M 1(x, c)$ は未知語 $x$ が最下位クラス $c$ に所属する確信 度である。

\section{$4 \cdot 2$ 評 価 実 験}

本節では，2段階での所属クラス推定の有用性につい て，実際にデータセットを用いて行った評価実験につい て述べる.

データセットは, 食べ物や飲み物の名前を表す単語と, それが所属する最下位クラスと, 関係のある中間クラス との組 1564 組によって構成されている. データセット中 の最下位クラスと中間クラスは, 図 2 に示したオントロ ジー上のものである. 最上位クラスは「飲食物」 1 個で あり，その下位概念として 6 個の中間クラスが位置付け られている.さらに, 中間クラスの下位概念として, 最 大で 7 個, 最小で 1 個の最下位クラスが位置付けられて おり，その総数は 21 個である.

最下位クラスへの確信度 $C M 1$ の付与には, 最大エン トロピーモデルを用いた [Berger 96]. つまり, 未知語 $x$ の文字列を入力として, 最大エントロピーモデルにより 出力される事後確率 $p(c \mid x)$ を, 確信度 $C M 1(x, c)$ とし て各最下位クラスに付与する.

$C M 1(x, c)=p(c \mid x)=\exp \left(\boldsymbol{w}_{c} \cdot \boldsymbol{\phi}(x, c)\right) / Z$

ここで, $\phi(x, c)$ は素性ベクトル, $\boldsymbol{w}_{c}$ は素性ベクトルに 対する最下位クラス $c$ ごとの重みベクトル,「.」はベクト ルの内積演算を表す演算子, $Z$ は $\sum_{c \in C_{l}} C M 1(x, c)=1$ $\left(C_{l}\right.$ は最下位クラスの集合) を保証する正規化係数であ る. 素性として, 文字 $\mathrm{n}$-gram $(\mathrm{n}=1,2,3)$ と文字種を 用いた [Otsuka 13]. 文字 n-gram は, 単語中にそれが存 


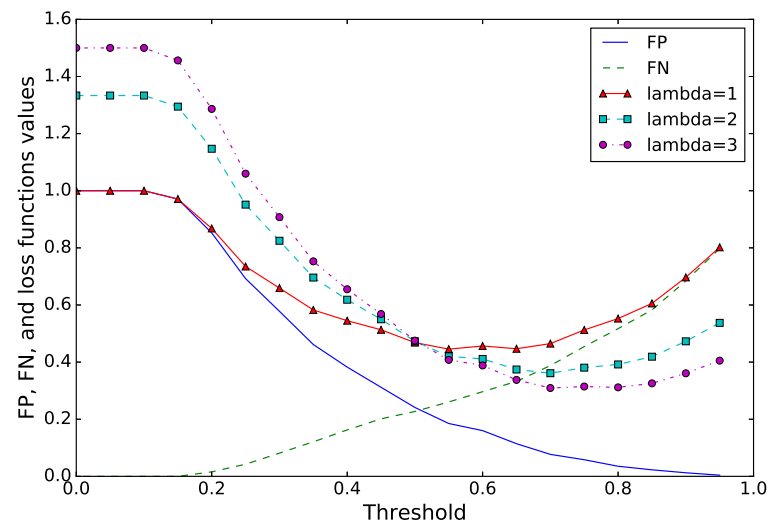

図 5 しきい值 $\theta_{1}$ を変化させた際の損失関数

在すれば素性值が 1 ，なければ 0 となる．文字種はひら がな, カタカナ, アルファベット, 漢字の 4 種類で, 単 語中にその文字種の文字が存在すれば素性值は 1 , なけ れば 0 となる.

確信度に対するしきい值 $\theta_{k}(k=1,2)$ の決定には, 駒 谷らの手法 [駒谷 02] を用いた。この手法では, 詔った 推定結果を受理してしまう割合（偽陽性率 False Positive Rate: FP) と, 正しい推定結果を棄却してしまう割合（偽 陰性率 False Negative Rate: FN）に重みをつけた損失関 数を用いている. 損失関数は, FP に重みを与えた $(\lambda$.

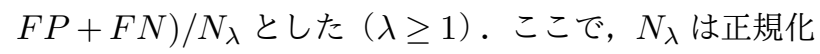
係数である. 対話システムでは誤った知識の獲得（FPに 対応）は損失が大きいため避ける方がよいという戦略を, この損失関数で反映させる. 本研究では, この損失関数 の值が最小となるしきい值を採用した。

実験の手順を以下に述べる. まず，単語を入力として， 最大エントロピーモデルにより各最下位クラスに確信度 $C M 1$ を付与し, $C M 1$ が最大となる最下位クラス $\hat{c} を$ 求めた. 最大エントロピーモデルの学習及び $C M 1$ の付 与は 10 分割交差検証により行い, 全ての単語について $\hat{c}$ とその確信度を求めた. $\hat{c}$ とデータセット中の最下位ク ラスの正解とが一致すれば, 推定結果は正解とした。 次 に, その結果に基づいて, 損失関数が最小となるしきい 值 $\theta_{1}$ を決定した. $C M 1$ が $\theta_{1}$ 未満となった単語につい て, 式 (1)によって確信度 $C M 2$ を算出し, 同様にしき い值 $\theta_{2}$ を決定した。最後に，2段階の各推定において正 解クラスを推定できた割合を算出した。

しきい值 $\theta_{k}$ の值は, 全データを使用して, 以下のよ うに決定した。 まず, 確信度 $C M 1$ についてのしきい值 $\theta_{1}$ を変化させたときの, 損失関数 $(\lambda \cdot F P+F N) / N_{\lambda}$ の 值を調查した。 図 5 に, $\theta_{1}$ を 0.05 刻みで変化させたと きの $F P, F N$ と損失関数の值を示す. ここで, 横軸は $\theta_{1}$ の值, 縦軸は $F P, F N$ や損失関数の值を表す. FP への重み $\lambda$ を $\lambda=2,3$ と変化させた結果, $\theta_{1}=0.7$ の場 合に損失関数は最小となったため, この值を採用した。 $C M 1<0.7$ となった単語に対して同様の操作を行い, し
きい值 $\theta_{2}$ を 0.6 と定めた。ここで, $\lambda$ の值は, 誤ったク ラスを含む確認要求を出力する率と関連しており, ユー ザへの印象（満足度など）とは直接的に関係しない。本 研究では, 正しい推定結果を棄却する損失よりも, 誤つ た推定結果を受理する損失に重きを置く. 前者の場合, システムが誤ったクラスを獲得し，その後の会話が本来 の話題から逸れてしまう. 後者の場合, 最下位のクラス 獲得はできないが，会話を続けられる．前者の損失の方 が後者の 2,3 倍程度であると考えたため, $\lambda=2,3$ とし て調査した. 以上の調査は全データを用いて行ったため, closed な実験設定である. しかしながら, 交差検証を行っ ても值が大きく変わることはないと思われるため, 以下 の実験は上記のしきい值を用いて行った。

表 1 に 2 段階での所属クラス推定の結果を示す.デー タセット中の単語 1564 語のうち, 最下位クラスの推定結 果の確信度 $C M 1$ が 0.7 以上となった単語数は 700 語で あった，そのうち，推定結果が正しかった単語数は 663 語で，その正解率は 0.947 であった. また， $C M 1<0.7$ となった単語 864 語のうち, 中間クラスレベルの推定結 果の確信度 $C M 2$ が 0.6 以上となった単語数は 435 語で あった。 そのうち, 推定結果が正しかった単語数は 358 語で, その正解率は 0.823 であった.

最下位クラスの推定において, 異なるクラスの単語に 頻出する部分文字列をもつ場合, 推定結果が誤りとなる 傾向にあった。例えば，単語「焼きそばパン」の推定結 果は，正解の最下位クラス「パン・サンドイッチ」では なく,「兡類」であった.データセット中の「麺類」に所 属する単語には, 部分文字列「そば」を含むものが多く あった。このため,「麺類」に所属すると推定する際の， 部分文字列「そば」に対する重みが学習によって大きく なり, 推定結果が誤りとなったと考える.

中間クラスレベルの推定誤りの例として，単語「今川 焼き」の推定結果を, 正解クラス「お菓子」ではなく「和 食」と出力するケースが見られた。これは, 推定の手が かりが不十分な場合に，下位クラスを多く持つ中間クラ スが出力されやすい傾向に起因する.「お菓子」の下位ク ラス数は 2 個,「和食」の下位クラス数は 7 個であった。 中間クラスの推定が行わ机る場合は最下位クラスに高い 確信度を持ったノードはなく, さらに推定の手がかりが 十分でない場合は各最下位ノードが均等に同じような確 信度を持つことになる. そして，4·1 節で示したように 確信度 $C M 2$ を最下位クラスの確信度 $C M 1$ の単純な和 としているため, 下位クラスを多く持つ中間クラスの確 信度が高くなる傾向がある. CM 2 を算出する際に下位 クラスの数を考慮する方法の検討は今後の課題である.

最下位クラスの推定のみを行う場合, 正しい推定結果 に基づく確認要求を生成できる割合は $663 / 1564=0.423$ であった。これに加えて中間クラスレベルの推定も行う ことで, その割合は $(663+358) / 1564=0.653$ に増加し た.この結果から，2段階での未知語のクラス推定により， 


\begin{tabular}{|c|c|c|c|c|c|c|}
\hline \multirow[t]{3}{*}{ 表 1} & \multicolumn{4}{|c|}{ 推定結果が受理される } & \multirow{3}{*}{$\begin{array}{l}\text { 推定結果が } \\
\text { 棄却される }\end{array}$} & \multirow{3}{*}{ 合計 } \\
\hline & \multicolumn{2}{|c|}{ 推定が正しい } & \multicolumn{2}{|c|}{ 推定が誤り } & & \\
\hline & 最下位 & 中間 & 最下位 & 中間 & & \\
\hline 単語数 & 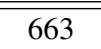 & $\underline{\mathbf{3 5 8}}$ & 37 & $\overline{777}$ & 4429 & 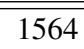 \\
\hline 割合 & \multicolumn{2}{|c|}{0.653} & \multicolumn{2}{|c|}{0.073} & 0.274 & 1.000 \\
\hline
\end{tabular}

適切な確認要求を出力してユーザとの対話を継続できる 割合が $54.4 \%$ 増加することが示された（0.653/0.423= 1.544）。2 章で述べた通り，中間クラスレベルの推定結果 を用いた確認要求を出力した場合には未知語のより詳細 なクラス獲得を行うことはできないが, 確認要求により 自然な対話を継続できるという点に価值があると考える.

\section{5. ユーザ発話を利用した正しいクラスに基づ く確認要求の抽出}

本章では, 確認要求に含めたクラス推定結果が正しい かどうかを判別可能とするために，正しいクラスに基づ く確認要求を抽出する実験を行う. まず, 確認要求前後 のユーザ発話やそれらの関係を分析し，正しいクラスに 基づく確認要求の抽出に有効と考えられるユーザ発話中 の表現を素性として設計する. 次に，クラウドソーシン グで収集したやりとりを対象に，設計した素性を用いて 確認要求に含めたクラスの正誤判別を行う分類器を構築 し，正しいクラスに基づく確認要求の抽出性能を調査す る.なお，4 章の実験とは，オントロジー中のクラス数 などの実験設定は一部異なる。

\section{$5 \cdot 1$ 素 性 設 計}

本節では，正しいクラスに基づく確認要求を抽出する ために設計した 11 種類の素性について述べる。その一 覧を表 2 に示す。 U1，S1，U2 はそれぞれ，確認要求前 のユーザ発話, 確認要求, 確認要求に対するユーザ応答, を表す.f1 から f6 はU2に，f7 からf10 はU1に，f11 はU1 とU2 との関係に，それぞれ着目している，例え ば，素性 f1 はU2 に同意表現が含まれているかにより素 性值が決まる．素性 f9 は，U1 に疑問詞が含まれている かにより素性值が決まる。

ここでは，システムがある単語についての正しいクラ スあるいは誤ったクラスに基づく確認要求を行った場合, 確認要求前後のユーザ発話間にはそれぞれ異なった傾向 が現れることを仮定している．収集した応答のデータか らそれぞれの傾向を分析し，それらを素性で表現する。紙 面の都合上，それぞれの傾向と素性として設定した表現 との一部を，例を示しながら説明する．また，説明を省 略した素性について，その設定を述べる。
表 2 設計した素性

\begin{tabular}{l|l}
\hline f1 & U2 が S1 への同意表現を含む \\
f2 & U2 が S1 への反対表現を含む \\
f3 & U2 が S1 への訂正表現を含む \\
f4 & U2 が S1 で用いられたクラスを含む \\
f5 & U2 が S1 で用いられていないクラスを含み, \\
& かつ S1 への訂正表現を含まない \\
f6 & U2 が S1 による話題転換を防止する語を含む \\
\hline f7 & U1 が S1 で用いられたクラスを含む \\
f8 & U1 が S1 で用いられていないクラスを含む \\
f9 & U1 が疑問詞を含む \\
f10 & U1 の表現と S1 で用いられたクラスとの不一致 \\
\hline f11 & U1 と U2 とで共通した単語が出現
\end{tabular}

$\S 1$ 正しいクラスに基づく確認要求前後のユーザ発話に 現れる傾向

正しいクラスに基づく確認要求に対し，ユーザは U2 で同意する傾向にある。以下に例を示す。

U1：鍋料理と言えば常夜鍋だよね。

S1：冬になるとお鍋が食べたくなりますよね。

U2: そうですね。

この例では，単語「常夜鍋」についての正しいクラス「鍋 料理」を用いた確認要求 S1 に対して, 被験者はU2 で同 意を示している. まずこれを素性 f1 で表現する.「そうで すね」,「はい」など 15 種類の文字列を同意表現とした。

さらに，この U2 での同意表現が S1 の確認要求に対 するものであることを裏付けるために, 確認要求に用い たクラスがU1にも含まれていたか否かを考慮し，これ を素性 $\mathrm{f} 7$ とする。これは，U1 と S1 でトピックが変わ らずに続いていることを示唆しており，この結果 U2 が S1 の内容に対する応答であることも期待できる．上記 の例では，U1 でユーザが「鍋料理」を含む文を入力した 後に，S1 で鍋に関する話題が続いており，このことから U2 の同意表現が S1 の確認要求に対するものであると解 釈できる.これにより, S1 の確認要求が誤ったクラスを 含んでいた場合に，ユーザが確認要求の内容を無視し話 を流そうとして，U2で「そうだね」のような同意表現を 用いた場合の誤判定の防止を狙う。

確認要求に含めたクラスが正しい場合，ユーザは U1 で用いた単語についての話をU2 でも継続する傾向にあ る。以下に例を示す。

U1 : 東南アジアの国々でカオマンガイは食ベら れるよ

S1: 最近では日本でも手軽にエスニックフード 
が食べられますよね。

U2：日本でもカオマンガイのおいしいお店があ るよね

この例では, 単語「カオマンガイ」についての正しいク ラス「エスニックフード」を含む確認要求 $\mathrm{S} 1$ に対して, ユーザはU2 で, U1 と同様に「カオマンガイ」について の文を入力している。これを素性 $\mathrm{f} 11$ で表現する.

$\S 2$ 誤ったクラスに基づく確認要求前後のユーザ発話に

\section{現れる傾向}

確認要求に含めたクラスが誤りである場合，ユーザは U2 で確認要求に対する反対表現を用いる傾向にある. 以 下に例を示す。

U1：カルパッチョは美味しいですよね。

S1：夏に食べるアイスは冷たくていいですよ

ね。

U2 : カルパッチョはアイスじゃないよ。

この例では, 単語「カルパッチョ」についての䛊ったク ラス「アイス」を用いた確認要求 $\mathrm{S} 1$ に対して, 被験者 はU2で「アイスじゃない」と反対している．これを素 性 f2 で表現する.「（S1に含めたクラス）ではない」,「違 う」など 17 種類の文字列を反対表現とした。

ユーザが誤ったクラスに基づく確認要求によって話題 が変わってしまったと感じた際, U2 で話題を U1 のもの に戻そうとする傾向にある，以下に例を示す.

$\mathrm{U} 1$ : サングリアのフルーティーな甘さが好き $\mathrm{S} 1:$ 洋菓子は味が濃厚なものが多いですよね。

$\mathrm{U} 2$ : お酒の話だよ?

この例では「サングリア」についての発話 U1 に対して, システムは誤ったクラス「洋菓子」を含む確認要求 S1 を出力している．それに対して，ユーザは話題が「洋菓 子」に変わってしまうのを防ぐため，U2 で単語「サング リア」の正しいクラス「酒」についての話がしたいと主 張する傾向にある。このように，ユーザが話題転換を防 止する際には, U2 中に確認要求に用いていないクラス と, 話題転換を防ぐための「話」という語が出現する傾 向にある。これを素性 f5, f6 で表現する。素性 f6 では, 「話」という 1 種類の文字列を話題転換を防ぐための語 とした.

\section{$\S 3$ 説明を省略した素性}

説明を省略した素性について，設定した表現やクラス を述べる．素性 f 3 では「（S1に含めていないクラス）だ よ」,「(S1に含めていないクラス) です」など 6 種類の 文字列を訂正表現とした。素性 f5, f8 では, 確認要求に 用いた 20 クラス $* 2$ の他に,「チーズ」,「パスタ」など 5 クラスを設定した。素性 f5 は, U2 中に S1 に含めてい

\footnotetext{
*2 4 章の実験で使用した最下位クラスの集合とは異なる．実験 で用いるシステムの拡張・改善のためクラス集合を若干変更し たが，実験結果や結論への影響は小さいと考える.
}

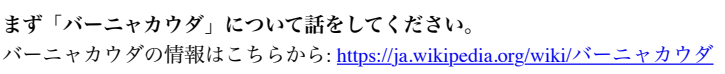

はじめからやり直す

図 6 実験に用いたシステムの GUI

ないクラスが現れ，かつ素性 f3 の訂正表現が現れない場 合とした．素性 f9 は,「どこの」,「何を」など 18 種類の 文字列を疑問詞とした．素性 $\mathrm{f} 10$ は，U1 中に「食べる」 「飲む」という表現があった場合に，それらと S1に含ま れるクラスとの不一致に着目する。具体的には，(1) U1 中に「食べる」やその活用形が含まれる場合に，S1 中に 「飲み物」に関するクラスが含まれるかどうか，(2) U1 中 に「飲む」やその活用形が含まれる場合に，S1 中に「食 ベ物」に関するクラスが含まれるかどうか，により素性 值を決める。U1 中に「食べる」「飲む」の活用形が含ま れているか否かの判定には, $\mathrm{MeCab}^{* 3} に よ る$ 形態素解析 の結果を用いた。

\section{$5 \cdot 2$ クラウドソーシングによるユーザ応答収集}

クラウドソーシングにより 100 人のワーカに依頼し, 暗黙的確認要求に対する応答を収集した。依頼はクラウ ドワークス ${ }^{* 4}$ のサービスを利用して行った。データ収集 は (1) ワーカがある単語を含む発話を入力，(2) システム がそれに対する暗黙的確認要求を出力，(3) ワーカがその 確認要求に対する応答を入力，という手順を，指定した 20 個の単語について繰り返すことにより行った．自然な 応答を収集するため, 暗黙的確認要求に対する応答内容 については特に制約は課さなかった。

実験に用いたシステムの GUI を図 6 に示す.「YOU」 で始まる文がワーカの発話を,「SYSTEM」で始まる文が システムの発話を表している，ワーカには，上記の手順 (1) で図 6 最上部の黒字の文で指定した単語を含む発話 を行うよう依頼した。また，指定した単語がわからない 場合は，その単語について記述された Wikipedia ページ のリンク（図 6 上部）を適宜参照して，やりとりを行う よう依頼した。これは, 単語についての知識がないせい で，システムの出力した確認要求の内容が正しいか誤り かわからないまま，ユーザが応答を入力することを防ぐ ためである.

手順 (2) で出力する確認要求は, 指定した単語につい ての正しいクラスを用いたものを 10 文，誤ったクラス を用いたものを 10 文，それぞれ人手で作成した。例え ば，単語「シュラスコ」に対して，正しいクラス「肉料 理」を用いた確認要求は,「お肉を見ると気分が高まりま

\footnotetext{
*3 http://taku910.github.io/mecab/

$* 4$ https://crowdworks.jp
} 
表 311 種類の素性全てを用いた場合と素性 f1，f2 のみを用いた 場合との分類結果

\begin{tabular}{c|c|r|c}
\multirow{2}{*}{ 用いた素性 } & 出力 & \multicolumn{2}{|c}{ 正解 } \\
\cline { 2 - 4 } & 正しい & 誤り \\
\hline \multirow{2}{*}{11 種全て } & 正しい & 724 & 298 \\
\cline { 2 - 4 } & 誤り & 254 & 680 \\
\hline \multirow{2}{*}{ 11, f2 のみ } & 正しい & 391 & 297 \\
\cline { 2 - 4 } & 誤り & 587 & 681
\end{tabular}

すよね」である，一方で，単語「サングリア」に対して， 誤ったクラス「洋菓子」を用いた確認要求は,「洋菓子は 味が濃厚なものが多いですよね」である．また，手順 (1) でワーカが入力した発話が疑問文や否定文であった場合 は, 確認要求をより自然なものにするために, 手順 (2)で 確認要求の文末を変化させて出力するようにした。例え ば，ユーザが「シュラスコって食べたことない」と否定 文を入力したとする. 通常の確認要求は「お肉を見ると 気分が高まりますよね」であるが，「食べたことがない」 と言った後に，食べたことを前提とした確認要求を行う のは不自然である，そのため，これに代えて「お肉を見 ると気分が高まりますし，ぜひ食べてください」と，対 象の飲み物・食べ物を勧めるような表現を文末に加えて 出力した.

依頼により，98人のワーカから 1956 のやりとりを収 集した。このうち半分は正しいクラスを含む確認要求に ついてのもので, 残りの半分は誤ったクラスを含む確認 要求についてのものである. 100 人のワーカのうち, 確 認要求後の応答において指定した単語 1 語のみを入力し 続けたワーカ 1 人と, 同じ文を入力し続けたワーカ 1 人 のデータは除外した.さらに, 確認要求後の応答が空白 であった 4 つのやりとりも除外した.

\section{$5 \cdot 3$ 評 価 実 験}

本節では，設計した素性を利用した正しいクラスに基 づく確認要求の抽出性能について，収集したデータを対 象に評価実験を行った結果について述べる．誤った知識の 獲得を避けるという目的から，正しいクラスに基づく確 認要求の抽出に注目し，その適合率を重視する．まず，ク ラウドソーシングにより収集した 1956 のやりとりから， $5 \cdot 1$ 節で素性として定義した表現やクラスの有無をそれ ぞれ検出した．各々の素性值は，設定した表現やクラスな どが含まれていればTrue，そうでなければFalse とした. 次に，10 分割交差検証により決定木分析を行った。評価指 標として，正しいクラスに基づく確認要求を抽出する際の 適合率，再現率を用いた。決定木分析は $\mathrm{Weka}^{* 5}$ (Version 3.8.1) の J48 を用いて行い，パラメータはデフォルト值 をそのまま用いた。

確認要求に対する同意表現，反対表現のみを考慮して 設計した素性 f1，f2 を用いる手法をべースラインとし，

*5 http://www.cs.waikato.ac.nz/ml/weka/
表 4 素性を 1 つ除いた場合の適合率，再現率，F 值

\begin{tabular}{c|r|r|r} 
除いた素性 & 適合率 & 再現率 & $\mathrm{F}$ 值 \\
\hline \hline なし & 0.708 & 0.740 & 0.724 \\
$\mathrm{f} 1$ & 0.703 & 0.745 & 0.723 \\
$\mathrm{f} 2$ & 0.688 & 0.740 & $\underline{0.713}$ \\
$\mathrm{f} 3$ & 0.698 & 0.743 & $\underline{0.720}$ \\
$\mathrm{f} 4$ & 0.659 & 0.873 & 0.751 \\
$\mathrm{f} 5$ & 0.688 & 0.761 & 0.723 \\
$\mathrm{f6}$ & 0.704 & 0.738 & 0.721 \\
\hline $\mathrm{f} 7$ & 0.684 & 0.753 & $\underline{0.717}$ \\
$\mathrm{f} 8$ & 0.670 & 0.780 & 0.721 \\
$\mathrm{f} 9$ & 0.698 & 0.751 & 0.724 \\
$\mathrm{f} 10$ & 0.698 & 0.739 & $\underline{0.718}$ \\
\hline $\mathrm{f} 11$ & 0.697 & 0.761 & 0.728
\end{tabular}

11 種類の素性全てを用いた場合の結果との比較を行った. それぞれの分類結果を表 3 に示す．前者では，正しいクラ スに基づく確認要求を抽出する際の適合率は $391 /(391+$ $297)=0.568$, 再現率は $391 /(391+587)=0.400$ であっ た。一方後者では, 適合率は $724 /(724+298)=0.708$, 再現率は $724 /(724+254)=0.740$ であった。これらか ら, 確認要求に対する同意表現や反対表現以外の表現を 考慮することで, 正しいクラスに基づく確認要求の抽出 性能が向上することがわかった。

正しいクラスに基づく確認要求の抽出に有効な素性に ついて議論する．まず， 11 種類の素性のうち 1 つを除外 した際の，それぞれの適合率，再現率， $\mathrm{F}$ 值を 表 4 に示 す.「除いた素性」が「なし」とは，11 種類全ての素性 を用いた場合のことである。素性を 1 つ除外した際に F 值が小さくなるもの，つまり抽出に有効な素性上位 4 つ は, 順に素性 $\mathrm{f} 2, \mathrm{f} 7, \mathrm{f} 10, \mathrm{f} 3$ であった。 次に, 生成さ れた決定木から分析を行った. 決定木のノード数は 13 , リーフ数は 14 であった。決定木の上部に現れる素性，つ まり分類における影響力の強い素性上位 5 つは，順に素 性 f3，f10，f2，f7，f5 であった。表 4 の結果と合わせ ると, 確認要求前のユーザ応答も考慮して設計した素性 （f7, f10）が, 正しいクラスに基づく確認要求の抽出に 重要であることが示唆されている.

除くことで $\mathrm{F}$ 值が向上した素性について述べる。表 4 より, 素性 $\mathrm{f} 4, \mathrm{f} 9, \mathrm{f} 11$ を除いた際の F 值が, 全ての素 性を用いた場合の $\mathrm{F}$ 值以上となっている．特に，素性 $\mathrm{f} 4$ を除いた場合では再現率が $10 \%$ 以上向上した。実験デー タ中には, 確認要求 S1 が誤ったクラスを含む場合でも, 元々の U1 とは無関係に, 単に S1に同調して応答 U2 で 同じクラスを用いた発話を行う場合が多数見られた。素 性 f4 は，S1 とU2 に同じクラス名が含まれるかどうか を表す素性であるが，その素性值がTrueであるケースに は, 誤ったクラスに基づく確認要求が行われた場合が半 数以上含まれていた。このことから, 素性 $\mathrm{f} 4$ を用いた場 
合は「誤ったクラスが含まれる」とより多く出力するよ う決定木が学習されていたのに対して，これを除いた場 合には「正しいクラスが含まれる」と出力する回数が増 えた。これにより, 素性 $\mathrm{f} 4$ を取り除いた場合, 適合率は 下がったものの, 再現率は向上するという結果になった。 ただし，これらの場合でも適合率は全ての素性を使った 場合の方が高い，実際のシステムでは，単語についての 誤った知識を獲得することを避けるため，再現率を犠牲 にしても適合率を高くするように調整しなくてはならな い場合がある。この際にどのように素性選択をすれば良 いかは，目標とする適合率に応じて変わってくる．これ は今後調査していく予定である.

本研究においては, 誤った知識の獲得を避けることが 重要なため, 誤ったクラスに基づく確認要求に対し「正し いクラスが含まれる」と出力された場合を調査した。こ のようなケース 298 のうち, 203 のやりとりは素性值が 全て False となるものであった。例を以下に示す.

$$
\begin{aligned}
& \mathrm{U} 1: \text { :ルフィーユっておいしいよね } \\
& \mathrm{S} 1: \text { 新鮮な魚は美味しいですよね。 } \\
& \mathrm{U} 2 \text { : おいしいものは大好きです }
\end{aligned}
$$

この例では, システムは「ミルフィーユ」についての誤つ たクラス「魚料理」を用いた確認要求を行っている. U1, U2 のどちらにも，素性として設計した表現やクラスが含 まれていない。このような場合には「正しいクラスが含 まれる」と出力するよう決定木が学習されたため, 分類 が誤りとなった。また，U1 とU2 との両者に「おいしい」 という単語が含まれているが，この単語は食べ物や飲み 物についての発話を行う際に一般的に用いられるもので あり，正しいクラスに基づく確認要求の抽出に有効とは 言えない. 応答内容を制約するインストラクションは特 に課していないため，このような応答も多く存在する.

今後は, 複数の対話における同じ確認要求に対するユー ザ発話を利用することで，正しいクラスに基づく確認要求 をより高い適合率で抽出する手法の開発に取り組む. 誤つ たクラスに基づく確認要求に対し，ユーザが上記の例の ような発話を行うと, システムは単語についての誤った 知識を獲得してしまう.これを防ぐために, 複数のユー ザから得られた発話に基づく分類結果を総合して考慮し, 正しい知識のみを獲得することを狙う。

\section{6. おわりに}

本稿では，ユーザが未知語を含む発話を行った際に，暗 黙的確認を用いてより自然な対話を継続しつつそのクラ スを獲得する手法を提案した。そのうち，未知語の所属 クラスを 2 段階で推定する手法について，実際にデータ セットを作成して評価実験を行った。その結果，最下位 クラスの推定のみを行う場合に比べ， 2 段階での推定を 行うことで, 適切な確認要求の生成が期待できる割合が
0.423 から 0.653 に増加することを示した。 また，正し いクラスに基づく確認要求を抽出するための素性設計と, クラウドソーシングによって収集した応答を対象とした 分類器の評価実験を行った。その結果から，正しいクラ スに基づく確認要求の抽出には, 確認要求に対する応答 だけでなく，確認要求前の発話も考慮することが有効で あることを示した。

今後は, 暗黙的確認による未知語のクラス獲得手法が, 明示的な質問によるものに比べてユーザに煩わしさを感 じさせないという仮説を検証するため，実際のユーザを 対象に印象評価実験を行う。また，現在システムの知識 として仮定しているオントロジーの階層構造は単純なも のであるため，実際の料理ジャンルに即したものになる よう構造の見直しを行う必要がある.ささに，正しいク ラスに基づく暗黙的確認要求の抽出性能を向上させるた めに，複数のユーザから得られた発話に基づく分類結果 を利用する手法の開発に取り組む。このとき，高い適合 率で抽出を行うためには再現率をどの程度犠牲にする必 要があるかについても調査を行う.

\section{謝辞}

本研究の一部は JSPS 科研費 JP16H02869 の助成を受 けた。

\section{$\diamond$ 参 考 文 献 $\diamond$}

[Banerjee 07] Banerjee, S. and Rudnicky, A. I.: Segmenting meetings into agenda items by extracting implicit supervision from human note-taking, in Proc. International Conference of Intelligent User Interfaces (IUI), pp. 89-92 (2007)

[Berger 96] Berger, A. L., Pietra, S. A. D., and Pietra, V. J. D.: A maximum entropy approach to natural language processing, Computational Linguistics, Vol. 22, No. 1, pp. 39-71 (1996)

[Dingli 13] Dingli, A. and Scerri, D.: Building a hybrid: Chatterbot - dialog system, in Proc. International Conference on Text, Speech, and Dialogue (TSD), pp. 145-152 (2013)

[Gokcen 15] Gokcen, A. and Marneffe, de M.-C.: I do not disagree: Leveraging monolingual alignment to detect disagreement in dialogue, in Proc. Annual Meetings of the Association for Computational Linguistics (ACL), pp. 94-99 (2015)

[Higashinaka 14] Higashinaka, R., Imamura, K., Meguro, T., Miyazaki, C., Kobayashi, N., Sugiyama, H., Hirano, T., Makino, T., and Matsuo, Y.: Towards an open-domain conversational system fully based on natural language processing, in Proc. International Conference on Computational Linguistics (COLING), pp. 928-939 (2014)

[Higashinaka 15] Higashinaka, R., Funakoshi, K., Araki, M., Tsukahara, H., Kobayashi, Y., and Mizukami, M.: Towards taxonomy of errors in chat-oriented dialogue systems, in Proc. Annual Meeting of the Special Interest Group on Discourse and Dialogue (SIGDIAL), pp. 87-95 (2015)

[Holzapfel 08] Holzapfel, H., Neubig, D., and Waibel, A.: A dialogue approach to learning object descriptions and semantic categories, Robotics and Autonomous Systems, Vol. 56, No. 11, pp. 1004-1013 (2008)

[Kobori 16] Kobori, T., Nakano, M., and Nakamura, T.: Small talk improves user impressions of interview dialogue systems, in Proc. Annual Meeting of the Special Interest Group on Discourse and Dialogue (SIGDIAL), pp. 370-380 (2016)

[駒谷 02] 駒谷 和範, 河原 達也 : 音声認識結果の信頼度を用いた効 
率的な確認・誘導を行う対話管理, 情報処理学会論文誌, Vol. 43 , No. 10, pp. 3078-3086 (2002)

[Komatani 09] Komatani, K. and Rudnicky, A. I.: Predicting bargein utterance errors by using implicitly supervised ASR accuracy and barge-in rate per user, in Proc. Annual Meeting of the Association for Computational Linguistics and International Joint Conference on Natural Language Processing (ACL-IJCNLP), pp. 89-92 (2009)

[Komatani 16] Komatani, K., Otsuka, T., Sato, S., and Nakano, M.: Question selection based on expected utility to acquire information through dialogue, in Proc. Intenational Workshop on Spoken Dialogue Systems (IWSDS) (2016)

[Lee 09] Lee, C., Jung, S., Kim, S., and Lee, G. G.: Example-based dialog modeling for practical multi-domain dialog system, Speech Communication, Vol. 51, No. 5, pp. 466-484 (2009)

[Marneffe 09] Marneffe, de M.-C., Grimm, S., and Potts, C.: Not a simple yes or no: Uncertainty in indirect answers, in Proc. Annual Meeting of the Special Interest Group on Discourse and Dialogue (SIGDIAL), pp. 136-143 (2009)

[Meng 04] Meng, H., Ching, P. C., Chan, S. F., Wong, Y. F., and Chan, C. C.: ISIS: An adaptive, trilingual conversational system with interleaving interaction and delegation dialogs, ACM Transactions on Computer-Human Interaction (TOCHI), Vol. 11, No. 3, pp. 268-299 (2004)

[Otsuka 13] Otsuka, T., Komatani, K., Sato, S., and Nakano, M.: Generating more specific questions for acquiring attributes of unknown concepts from users, in Proc. Annual Meeting of the Special Interest Group on Discourse and Dialogue (SIGDIAL), pp. 70-77 (2013)

[Papaioannou 17] Papaioannou, I. and Lemon, O.: Combining chat and task-based multimodal dialogue for more engaging HRI: A scalable method using reinforcement learning, in Proc. the Companion of the 2017 ACM/IEEE International Conference on Human-Robot Interaction, pp. 365-366 (2017)

[Pappu 14] Pappu, A. and Rudnicky, A. I.: Learning situated knowledge bases through dialog, in Proc. Annual Conference of the International Speech Communication Association (INTERSPEECH), pp. 120-124 (2014)

[Takahashi 02] Takahashi, Y., Dohsaka, K., and Aikawa, K.: An efficient dialogue control method using decision tree-based estimation of out-of-vocabulary word attributes, in Proc. International Conference on Spoken Language Processing (ICSLP), pp. 813-816 (2002)

[Yu 16] Yu, Z., Xu, Z., Black, A. W., and Rudnicky, A.: Strategy and policy learning for non-task-oriented conversational systems, in Proc. Annual Meeting of the Special Interest Group on Discourse and Dialogue (SIGDIAL), pp. 404-412 (2016)

〔担当委員：颯々野学〕

2017 年 6 月 6 日 受理

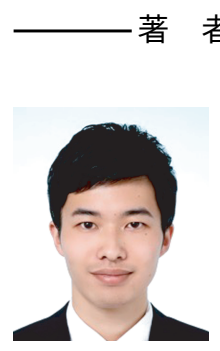

\section{者 紹 介}

\section{大野 航平(学生会員)}

2016 年大阪大学工学部電子情報工学科卒業. 同年より, 同 大学院工学研究科電気電子情報工学専攻博士前期課程在学 中. 対話システムの研究に従事. 情報処理学会, 言語処理 学会各学生会員.

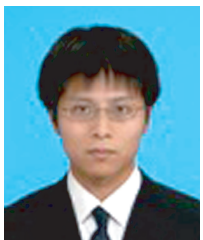

\section{武田＼cjkstart龍}

2006 年京都大学工学部情報学科卒業. 2008 年同大学院情 報学研究科修士課程修了. 2011 年同研究科博士後期課程 修了. 博士 (情報学) . 2011 2014 年株式会社日立製作所 中央研究所研究員. 2014 年より大阪大学産業科学研究所 助教. 主に音響信号処理 ・音声認識の研究に従事. IEEE, 情報処理学会, 日本音響学会各会員。

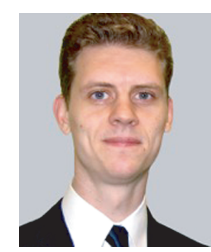

ニコルズ エリック

2002 年メリーランド州立大学コンピュータサイエンス学 部・日本語学部卒業. 2005 年奈良先端科学大学院大学情報 科学専攻修士課程修了. 2010 年同大学院情報科学専攻博 土 (工学) 課程修了. 同年 2013 年東北大学大学院情報科 学研究科研究員. 2013 年 (株) ホンダ・リサーチ・インス ティチュート・ジャパン入社. 現在, 同社シニア・リサー チャ. 自然言語処理，機械学習の研究に従事. Association for Computational Linguistics, 言語処理学会各会員.

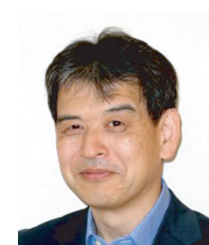

\section{中野 幹生(正会員)}

1988 年東京大学教養学部基礎科学科第一卒業. 1990 年同 大学院理学系研究科相関理化学専攻修士課程修了. 1990 2004 年日本電信電話（株）勤務. 1998 年東京大学博士（理 学). 2004 年（株）ホンダ・リサーチ・インスティチュー ト・ジャパン入社. 現在, 同社プリンシパル・リサーチャ. 対話システム, 音声言語理解の研究に従事. 情報処理学 会, 言語処理学会, 電子情報通信学会, 日本ロボット学会, ACM, IEEE 各会員.

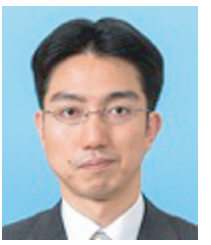

\section{駒谷 和範(正会員)}

1998 年京都大学工学部情報工学科卒業. 2000 年同大学院 情報学研究科知能情報学専攻修士課程修了, 2002 年同研究 科博士後期課程修了. 京都大学博士 (情報学) . 同年, 京 都大学大学院情報学研究科助手, 同助教, 2010 年名古屋 大学大学院工学研究科准教授を経て，2014 年より大阪大 学産業科学研究所教授. 主に音声対話システムの研究に従 事. 2008 2009 年米国カーネギーメロン大学客員研究員. 2010２014 年 JST さきがけ研究員兼務. 2013〜2017 年 SIGdial Scientific Advisory Committee 委員. 言語处理学会理事. 情報処理学会, 電子情報通信学会各会員. 